\title{
ASSESSMENT OF SOIL FERTILITY AND GROUNDNUT (ARACHIS HYPOGEAE) YIELD PERFORMANCE UNDER DIFFERENT WEEDING REGIMES
}

B. OSUNDARE

(Received 2 December 2011; Revision Accepted 28 March 2012)

\section{ABSTRACT}

A two - year field experiment was conducted at the Teaching and Research Farm of the Ekiti State University, Ado - Ekiti, Nigeria, during 2008 and 2009 cropping seasons to determine the effects of different weeding regimes on soil chemical properties and yield of groundnut (Arachis hypogeae). The experiment was laid out in a randomized complete block design (RCBD) with three replications. The different weeding regimes included: weeding once $\left(\mathrm{W}_{1}\right)$ at three weeks after planting (WAP); weeding twice $\left(\mathrm{W}_{2}\right)$ at 6 and 9 WAP; weeding thrice $\left(\mathrm{W}_{3}\right)$ at 3,6 and 9 WAP and no weeding $\left(\mathrm{W}_{0}\right)$, which served as the control. The results indicated that there were significant $(P=0.05)$ differences among the different weeding regimes with respect to their effects on yield of groundnut. Relative to the initial nutrient status of the soil before 2008 cropping season, the percentage decreases in soil organic carbon (SOC) after cropping, adduced to weeding regimes were $58,39,49$ and $28 \%$ for $W_{0}, W_{1}, W_{2}$ and $W_{3}$, respectively. $W_{1}$ and $W_{3}$ resulted in 7 and $14 \%$ increases in total $\mathrm{N}$, respectively, contrasting decreases of 48 and $40 \%$ for the respective $\mathrm{W}_{0}$ and $\mathrm{W}_{2}$. The percentage decreases in available $\mathrm{P}$ after cropping were $37,20,27$ and $8 \%$ for the respective $W_{0}, W_{1}, W_{2}$ and $W_{3}$. Across the two years of experimentation, weeding significantly increased groundnut seed yield from $0.43 \mathrm{tha}^{-1}$ for $\mathrm{W}_{0}$ to $1.23,0.96,1.51$ t ha ${ }^{-1}$ for $W_{1}, W_{2}$ and $W_{3}$, respectively.

KEY WORDS: Soil Fertility, Groundnut, Yield, Weeding.

\section{INTRODUCTION}

Groundnut (Arachis hypogeae) is one of the most valuable legumes, widely cultivated, especially in northern Nigeria. Poor weed management, pest infestation and disease infection have been identified as the major constraints to groundnut production in Nigeria (Preap, 2008; Ayeni, 2011). Groundnut is so sensitive to weed interference, especially at the early stages of growth, that, its seed yield can be reduced by as much as $80 \%$ (Preap, 2008; Ajakaye, 2010). Thus, to minimize the high seed yield reduction, associated with weed interference, the need to fashion out effective and timely weed removal in groundnut should not be ignored by farmers.

Previous studies (Kader, 2008; Idah, 2011; Owoseni, 2011) had demonstrated significant effects of weeding regimes on growth and yield of groundnut. In all the studies, significant differences among the different weeding regimes with respect to their effects on the growth and yield of groundnut were reported. Elsewhere, some studies (Delto, 2007; Stein, 2009 and Benor, 2011) had been conducted on the effects of different weeding regimes on soil nutrient status in groundnut field. These authors noted significant differences among the weed control options as regards their effects on soil chemical properties. However, in view of the paucity of published work on soil nutrient status, as affected by different weeding regimes in groundnut field in Nigeria, there is a dire need to accord research attention to determining the effects of different weeding regimes on soil nutrient status in groundnut field. Consequent upon this, this paper reports the results of a two - year trial, aimed at evaluating the influence of weeding regimes on soil chemical properties and the performance of groundnut in the basement complex soils of southwestern Nigeria.

\section{Materials and Methods}

Location: A two - year field experiment was conducted at the Teaching and Research Farm of the Ekiti State University, Ado - Ekiti, Nigeria, during 2008 and 2009 cropping seasons. Ado - Ekiti lies on latitude $7^{0} 30 \mathrm{~N}$ and longitude $3^{0} 54 \mathrm{E}$. The total annual rainfall during the period of investigation were 968 and $997 \mathrm{~mm}$ in 2008 and 2009, respectively. The mean annual temperature ranged between $26.3^{\circ} \mathrm{C}$ and $24.8^{\circ} \mathrm{C}$ in 2008 and 2009, respectively, while the average relative humidities were 66 and $79 \%$ in 2008 and 2009, respectively. The soil of the study site is an Alfisol (SSS, 2003) of the basement complex, highly leached, with low to medium organic matter content. The study site had earlier been cultivated to many arable crops, among which were cassava, maize, melon, cocoyam, rice before left fallow for some years before this research was carried out. The fallow vegetation (mainly shrubs) was manually slashed, after which the land was ploughed and harrowed.

Collection and analysis of soil samples: Prior to planting, ten core soil samples, randomly collected from

B. Osundare, Department of Crop, Soil, and Environmental Sciences, Ekiti State University, Nigeria. 
$0-15 \mathrm{~cm}$ soil depth, using a soil auger, were bulked inside a plastic bucket to form a composite sample, which was analyzed for physical and chemical properties. At the end of the second cropping season (2009), another soil samples, consisting five cores were collected per each treatment plot of $6 \mathrm{~m}^{2}$, thoroughly mixed inside a plastic bucket to form a composite sample, which was analyzed. The soil samples were air - dried, ground, and passed through a $2 \mathrm{~mm}$ sieve. The processed soil samples were analyzed in accordance with soil analytical procedures, outlined by IITA (1989).

Experimental design and treatments: The experiment was laid out in a randomized complete block design ( RCBD) with three replications. The different weeding regimes were: weeding once $\left(\mathrm{W}_{1}\right)$ at three weeks after planting (WAP); weeding twice $\left(\mathrm{W}_{2}\right)$ at 6 and 9 WAP; weeding thrice $\left(\mathrm{W}_{3}\right)$ at 3,6 and 9 WAP and no weeding $\left(\mathrm{W}_{0}\right)$ which served as the control. All the weeding operations were carried out manually, using a hand hoe. Each plot size was $3 \mathrm{~m} \times 2 \mathrm{~m}\left(6 \mathrm{~m}^{2}\right)$, while the experimental plot size was $14.5 \mathrm{~m} \times 8 \mathrm{~m}\left(116 \mathrm{~m}^{2}\right)$.

Planting and collection of data: In 2008 and 2009, planting was carried out in March 2 and March 5, respectively. Three groundnut seeds were sown per stand at a spacing of $60 \mathrm{~cm} \times 30 \mathrm{~cm}$, but later thinned to one seedling per stand at three weeks after planting $\left(55,555\right.$ plants $\left.\mathrm{ha}^{-1}\right)$. No fertilizer was applied throughout. At harvest, data were collected on fresh groundnut fodder and seed yield.

Statistical analysis: All the data collected were subjected to analysis of variance, and treatment means were compared, using the Duncan Multiple Range Test (DMRT) at $5 \%$ level of probability.

\section{RESULTS}

The physical and chemical properties of soil in the study site before 2008 cropping are presented in Table 1 .

Table 1: The physical and chemical properties of soil in the study site prior to 2008 cropping season.

\begin{tabular}{lc}
\hline Soil parameters & Values \\
\hline & \\
pH & 5.6 \\
Organic carbon $\left(\mathrm{g} \mathrm{kg}^{-1}\right)$ & 0.95 \\
Total nitrogen $\left(\mathrm{g} \mathrm{kg}^{-1}\right)$ & 0.58 \\
Available phosphorus $\left(\mathrm{mg} \mathrm{kg}^{-1}\right)$ & 0.86 \\
Exchangeable bases $\left(\mathrm{cmol} \mathrm{kg}^{-1}\right)$ & \\
Potassium & 0.44 \\
Calcium & 0.40 \\
Magnesium & 0.60 \\
Sodium & 0.51 \\
Acidity & 0.32 \\
Effective Cation Exchangeable Capacity (ECEC) & 2.27 \\
Texture (\%) & \\
Sand & 68.0 \\
Silt & 20.0 \\
Clay & 12.0 \\
Textural class & Sandy loam \\
\hline
\end{tabular}

Changes in soil chemical properties after 2009 cropping season: Table 2 shows soil nutrient status as affected by different weeding regimes after 2009 cropping season. Relative to the initial nutrient status of the soil before 2008 cropping season, the percentage decreases in the soil $\mathrm{pH}$ after 2009 cropping season, adduced to weeding regimes were $41,18,29$ and $9 \%$ for $W_{0}, W_{1}, W_{2}$ and $W_{3}$, respectively. Similarly, the percentage decreases in soil organic carbon (SOC) were 58, 39, 49 and $28 \%$ for $W_{0}, W_{1}, W_{2}$ and $W_{3}$, respectively. $W_{1}$ and $W_{3}$ resulted in 7 and $14 \%$ increases in total $\mathrm{N}$, respectively, as against decreases of 48 and $40 \%$ for the respective $W_{0}$ and $W_{2}$. The percentage decreases in available $P$ were $37,20,27$ and $8 \%$ for the respective $W_{0}, W_{1}, W_{2}$ and $W_{3}$. Similarly, $W_{0}, W_{1}, W_{2}$ and $W_{3}$ decreased exchangeable $\mathrm{K}$ by $43,18,32$ and $9 \%$, respectively. Exchangeable Ca decreased by 30, 15, 23 and $3 \%$ for the respective $W_{0}, W_{1}, W_{2}$ and $W_{3}$. Similarly, Mg decreased by 45,20 , 33 and $12 \%$ for the respective $W_{0}, W_{1}, W_{2}$ and $W_{3}$. The percentage decreases in exchangeable $\mathrm{Na}$ were 51,26 , 39 and $14 \%$ for the respective $W_{0}, W_{1}, W_{2}$ and $W_{3}$. 
Table 2: Soil chemical properties as affected by different weeding regimes after 2009 cropping season.

\begin{tabular}{|c|c|c|c|c|c|c|c|c|}
\hline \multirow{2}{*}{$\begin{array}{l}\text { Treatments } \\
\text { (Weeding regimes) }\end{array}$} & \multirow[b]{2}{*}{ pH } & \multirow{2}{*}{\multicolumn{2}{|c|}{$\begin{array}{l}\text { Org.C. Total N } \\
\left(\mathrm{g} \mathrm{kg}^{-1}\right) \quad\left(\mathrm{g} \mathrm{kg}^{-1}\right)\end{array}$}} & \multirow{2}{*}{$\begin{array}{l}\text { Av. P } \\
\left(\mathrm{mg} \mathrm{kg}^{-1}\right)\end{array}$} & \multirow{2}{*}{\multicolumn{4}{|c|}{$\begin{array}{l}\text { Exchangeable bases }\left(\mathrm{cmol}^{2} \mathrm{~kg}^{-1}\right) \\
\mathrm{K} \mathrm{Ca} \mathrm{Mg} \mathrm{Na}\end{array}$}} \\
\hline & & & & & & & & \\
\hline No weeding (control) & 3.3 & 0.40 & 0.30 & 0.54 & 0.25 & 0.28 & 0.33 & 0.25 \\
\hline Weeding once (3 WAP) & 4.6 & 0.58 & 0.62 & 0.69 & 0.36 & 0.34 & 0.48 & 0.38 \\
\hline $\begin{array}{l}\text { Weeding twice ( } 6 \text { and } 9 \\
\text { WAP ) } \\
\text { Weeding thrice }(3,6 \text { and }\end{array}$ & 4.0 & 0.48 & 0.36 & 0.63 & 0.30 & 0.31 & 0.41 & 0.31 \\
\hline 9 WAP ) & 5.1 & 0.68 & 0.66 & 0.79 & 0.40 & 0.39 & 0.53 & 0.44 \\
\hline
\end{tabular}

Seed and fresh fodder yield and number of days to $50 \%$ flowering: Table 3 shows the effects of different weeding regimes on seed and fresh fodder yield and number of days to $50 \%$ of groundnut. On the two - year average, weeding significantly increased groundnut seed yield from $0.43 \mathrm{tha}^{-1}$ for $\mathrm{W}_{0}$ to $1.23,0.96$ and 1.51 $t$ ha ${ }^{-1}$ for $W_{1}, W_{2}$ and $W 3$, respectively. Similarly, weeding significantly increased groundnut fresh fodder yield from $0.15 \mathrm{t} \mathrm{ha}^{-1}$ for $\mathrm{W}_{0}$ to $0.34,0.22$ and $0.43 \mathrm{t} \mathrm{ha}^{-1}$ for the respective $W_{1}, W_{2}$ and $W_{3}$. Weeding significantly reduced number of days to attainment of $50 \%$ flowering from 85 days for $W_{0}$ to 71,80 and 69 days for the respective $W_{1}, W_{2}$ and $W_{3}$.

Table 3: Effects of different weeding regimes on number of days to $50 \%$ flowering, seed and fresh fodder yield of groundnut.

\begin{tabular}{|c|c|c|c|c|c|c|c|c|}
\hline \multirow{2}{*}{$\begin{array}{l}\text { Treatments } \\
\text { (Weeding regimes) }\end{array}$} & \multicolumn{2}{|c|}{ Seed yield $\left(t \mathrm{ha}^{-1}\right)$} & \multicolumn{2}{|c|}{$\begin{array}{l}\text { Fodder yield } \\
\left(\mathrm{t} \mathrm{ha}^{-1}\right)\end{array}$} & \multicolumn{4}{|c|}{$\frac{\text { Number of days to } 50 \%}{\text { flowering }}$} \\
\hline & 2008 & 2009 Mean & 2008 & 2009 & Mean & 2008 & 2009 & Mean \\
\hline No weeding (control) & $0.46 \mathrm{~d}$ & $0.39 d \quad 0.43$ & $0.17 d$ & $0.12 d$ & 0.15 & $85 a$ & $83 a$ & 85 \\
\hline Weeding once (3 WAP) & $1.27 \mathrm{~b}$ & $1.19 \mathrm{~b} 1.23$ & $0.38 b$ & $0.29 b$ & 0.34 & $70 \mathrm{c}$ & $71 \mathrm{c}$ & 71 \\
\hline WAP) & $1.03 c$ & $0.89 \mathrm{c} 0.96$ & $0.24 \mathrm{c}$ & $0.19 c$ & 0.22 & $81 b$ & $78 b$ & 80 \\
\hline 9 WAP) & $1.58 \mathrm{a}$ & $1.44 \mathrm{a} 1.51$ & $0.46 \mathrm{a}$ & $0.40 \mathrm{a}$ & 0.43 & $70 c$ & $68 \mathrm{c}$ & 69 \\
\hline
\end{tabular}

Mean values in the same column followed by the same letter are not significantly different at $P=0.05$ (DMRT).

\section{DISCUSSION}

In this study, the decrease in soil organic carbon ( SOC ), after cropping, observed under the different weeding regimes can be ascribed to oxidation of the preserved and previously inaccessible organic matter, following its exposure to microbial action, as a result of tillage associated with hoe - weeding operations. The decrease in the SOC or soil organic matter ( SOM ), consequently accounts for the observed decreases in all other plant nutrients, as SOM is the reservoir of all other nutrients, that is, other nutrients are integrally tied to it ( Stein, 2009; Benor, 2011 ).

The decreases in virtually all the soil nutrients after cropping, associated with the no weeding treatment can be ascribed to the combined uptake of these nutrients from the soil system by both groundnut and weeds. The decrease in $\mathrm{N}$ after cropping is noteworthy. This is because, one would have expected an increase in $\mathrm{N}$ content of the soil under groundnut cultivation, as legumes generally, with the aid of the symbiotic bacteria in their root nodules are known for their ability to symbiotically fix atmospheric $\mathrm{N}$ into the soil. However, the decrease in $\mathrm{N}$, was due perhaps, to the detrimental effects of weed interference on groundnut, which consequently, may have inhibited the process of nodulation in groundnut, with resultant poor $\mathrm{N}$ fixation (Benor, 2011). This observation suggests that, although, legumes have the ability of improving soil $\mathrm{N}$ economy through symbiotic fixation of atmospheric nitrogen, however, for enhanced $\mathrm{N}$ fixation, the provision of an initial weed - free micro - environment for legumes is imperative. The decrease in $\mathrm{pH}$ (i.e. increased acidity ) after cropping, observed under all the weeding regimes can be attributed to the decreases in the exchangeable bases. The decreases in the exchangeable bases can be adduced to leaching (Delto, 2007). This is because the tillage that was involved in hoe - weeding operations may have resulted in increased porosity with resultant increased vulnerability of the soil to leaching losses. Also, the decreases in the exchangeable bases can be ascribed to uptake by weeds and groundnut during the growing period as reported by Stein (2009).

The increase in $\mathrm{N}$ after cropping, observed in the plots of single weeding ( 3 WAP ) and triple weeding ( 3,6 and 9 WAP ) treatments can be attributed to $N$ fixation by groundnut. This is because, the provision of an initial weed - free micro - environment at 3 weeks after planting, involved in these two weeding regimes may have enhanced nodulation process, with resultant enhanced N fixation (Delto, 2007; Benor, 2011). The low 
$P$ status of the soil after cropping can be ascribed to the high $P$ fixation capacity of the soil, resulting from formation of insoluble phosphate due to $\mathrm{P}$ adsorption onto the negatively charged clay. The decreases in other nutrients $(\mathrm{K}, \mathrm{Ca}, \mathrm{Mg}$ and $\mathrm{Na}$ ) can be adduced to uptake by weeds and groundnut. The decrease in $\mathrm{pH}$ can be attributed to the decreases in the exchangeable bases (Delto, 2007; Stein, 2009).

The highest groundnut seed yield consistently recorded for weeding thrice (3, 6 and $9 \mathrm{WAP})$, relative to weeding once ( 3 WAP) and weeding twice $(6$ and 9 WAP) is in agreement with the findings of Kader (2008); Idah (2011); Owoseni (2011), who found that groundnut weeded thrice $(3,6$ and 9 WAP) far out - yielded the one weeded once ( 3 WAP) and twice (6 and 9 WAP). This observation points to the superiority of weeding thrice treatment to other weeding treatments, appraised in this study. The superiority of weeding thrice treatment can be adduced to the low incidence of groundnut weed competition for growth resources (i. e. air, water, light, nutrients etc). This is because weeding thrice resulted in the provision of a weed - free micro environment for groundnut throughout the growing period. Conversely, groundnut suffered weed interference in the first five weeks of planting in the case of weeding twice (6 and 9 WAP) before first weeding was carried out at six weeks after planting. Similarly, groundnut suffered weed interference at later stages of growth after the first and only weeding at three weeks after planting in the case of weeding once treatment ( 3 WAP). This shows that, as far as groundnut is concerned, at least, three properly timed weedings are required to avert the problem of groundnut - weed competition throughout its growing period.

The significantly higher groundnut seed yield for weeding once ( 3 WAP) than its weeding twice (6 and 9 WAP) counterpart is noteworthy. This suggests that, first weeding, especially at three weeks after planting, unlike when it was delayed till six weeks after planting in the case of weeding twice (6 and 9 WAP) treatment, may have resulted in the provision of an initial weed - free micro - environment for proper establishment of groundnut before the first flush of weeds got established. Thus, the proper establishment, consequently accorded groundnut a higher competition advantage for growth factors over the weeds (Kader, 2008; Owoseni, 2011). This implies that, early weeding, especially at three weeks after planting is of immense significance in groundnut cultivation, and hence, should not be handled with levity.

From the findings of this study, it is apparent that, not the number of weedings carried out that actually matters, but timing weeding operations in such a way that they will coincide with the most critical stage in the life -cycle of crops, when they are most sensitive to weed interference. In view of the immense benefit that groundnut derived from early weeding, especially at three weeks after planting, hence, recommendation of properly timed weeding operations, especially in the first three weeks of planting for groundnut cultivation is imperative.

\section{CONCLUSION}

The significant increases in seed and fresh fodder yield of groundnut under the different weeding regimes can be ranked as: no weeding (control) < weeding twice ( 6 and 9 WAP) < weeding once ( 3 WAP) $<$ weeding thrice $(3,6$ and 9 WAP). Apart from $N$ that increased under weeding once ( 3 WAP) and weeding thrice ( 3,6 and 9 WAP) treatments, and decreased under no weeding and weeding twice ( 6 and 9 WAP), all other nutrients decreased under all the different weeding regimes after cropping.

\section{REFERENCES}

Ajakaye, B. I., 2010. Weeds and their effects on crops. Journal of Crop Improvement. (14): 220 - 225.

Ayeni, D. O., 2011. Principles and practices of weed management in the tropics. Weed Science Research. (17): $12-18$.

Benor, E. N., 2011. Maize performance and soil fertility as affected by different weeding frequency. Crop Science Journal. 15, (12):131 - 136.

Delto, F., 2007. Effects of weeding regimes and inorganic fertilization on grain yield of maize intercropped with melon in southwestern Nigeria. Crop Physiology. (26): $76-81$.

Idah, A. D., 2011. Groundnut yield as affected by tillage practices and mulching. Journal of Applied Sciences and Environmental Studies. 20, (18): $43-47$.

I I T A., 1989. Automated and semi - automated methods of soil and plant analysis. Manual Series No 7, I I T A, Ibadan, Nigeria.

Kader, M .O., 2008. Study on the effects of weed interference on the growth and yield of groundnut. Crop Protection. (18): 7 - 12.

Owoseni, J. J., 2011. Evaluation of the performance of groundnut under different weeding and irrigation regimes. Agricultural Science Journal. (11): 20 25.

Preap, B., 2008. Crop production and biological constraints in southwestern Nigeria. Journal of Food and Agriculture. 16, (12): $30-35$.

Soil Survey Staff (SSS), 2003. Keys to soil taxonomy, $9^{\text {th }}$ edition. USDA Natural Resources Conservation Services, U.S. Department of Agriculture, Washington D. C. 306.

Stein, K., 2009. Groundnut seed and fodder yield as affected by time of planting, weeding regimes and NPK fertilization. Crop Science Research. (14): $51-56$. 